\title{
Chemical composition of various plant extracts and their in vitro efficacy in control of Fasciola hepatica eggs
}

\section{Larice Tosi Marques ${ }^{1}$ (D) Roselena Abreu Guedes ${ }^{1}$ (D) Winner Duque Rodrigues ${ }^{2}$ (D) Anderson Barros Archanjo ${ }^{3}$ (D) Juliana Aparecida Severi, ${ }^{1,2}$ Is Isabella Vilhena Freire Martins 1,** $^{10}$}

'Programa da Pós-graduação em Ciências Veterinárias, Centro de Ciências Agrárias e Engenharias, Universidade Federal do Espírito Santo (UFES), Alegre, ES, Brasil.

${ }^{2}$ Departamento de Farmácia e Nutrição, Centro de Ciências Exatas, Naturais e da Saúde, Universidade Federal do Espírito Santo (UFES), Alegre, ES, Brasil.

3Programa de Pós-graduação em Biotecnologia, Centro de Ciências da Saúde, Universidade Federal do Espírito Santo (UFES), Vitória, ES, Brasil.

${ }^{4}$ Departamento de Medicina Veterinária, Centro de Ciências Agrárias e Engenharias, Universidade Federal do Espírito Santo (UFES), 29500-000, Alegre, ES, Brasil. E-mail: ivfmartins@gmail.com. .Corresponding author.

ABSTRACT: Fasciolosis has been diagnosed in cattle, goats, sheep and horses in southern and southeastern Brazil. Effective alternative treatments are the targets of study. One promising alternative is the use of plant extracts. The aim of this study was to perform phytochemical analysis of extracts of Eugenia uniflora L., Harpagophytum procumbens, Psidium guajava L. and Stryphnodendron adstringens, and to evaluate the in vitro efficacy of these extracts on ovicidal activity in Fasciola hepatica. Plant extracts were analyzed for phytochemical properties. F. hepatica eggs were collected directly from the gallbladders of animals diagnosed as positive for fasciolosis on post mortem examination. One hundred eggs were incubated with $3 \mathrm{ml}$ of each extract at concentrations of $0.10 \%, 0.25 \%$ and $0.50 \%$, albendazole $0.50 \%$ (positive control) or tap water (negative control). To determine anti larval efficacy of each plant extract, hatched eggs were counted and the averages were used. Phytochemical analysis revealed the presence of phenolic compounds, tannins and terpenes in most extracts. E. uniflora L. extract was $100 \%$ effective at $0.10 \%, \mathrm{H}$. procumbens was effective at $0.25 \%$ and $P$. guajava $L$. and S. adstringens extracts were $100 \%$ effective at all concentrations tested. Taken together, the data suggested that ovicidal activity in F. hepatica is due to the presence of these bioactive compounds.

Key words: Eugenia uniflora L., Harpagophytum procumbens, Psidium guajava L., Stryphnodendron adstringens, ovicidal activity on Fasciola.

Composição química de vários extratos vegetais e sua eficácia in vitro no controle de ovos de Fasciola hepática

RESUMO: A fasciolose tem sido diagnosticada em bovinos, caprinos, ovinos e equinos no sul e sudeste do Brasil, sendo que tratamentos alternativos mais eficazes são alvos de estudo. Umas das alternativas promissoras é o uso de extratos vegetais no controle dessa e outras enfermidades. O objetivo deste estudo foi realizar a análise fitoquimica dos extratos de Eugenia uniflora L., Harpagophytum procumbens, Psidium guajava L. e Stryphnodendron adstringens, além de avaliar a eficácia in vitro desses extratos na atividade ovicida em Fasciola hepatica. Os extratos vegetais foram obtidos e analisados para determinação fitoquímica. Ovos de F. hepatica foram coletados diretamente das vesiculas biliares de animais diagnosticados como positivos para fasciolose no exame post mortem. Cem ovos foram incubados com três mililitros de cada extrato nas concentrações de 0,10\%, 0,25\% e 0,50\%, de albendazol a 0,50\% (controle positivo) e água de torneira (controle negativo). Para determinar a eficácia de cada extrato vegetal os ovos eclodidos foram contados, e a média utilizada para os cálculos de eficácia. A análise fitoquímica revelou a presença de compostos fenólicos, taninos e terpenos na maioria dos extratos. O extrato de E. uniflora L. apresentou eficácia de $100 \%$ na concentração de $0,10 \%$, o de H. procumbens a $0,25 \%$ e os extratos de P. guajava L. e S. adstringens apresentaram $100 \%$ de eficácia em todas as concentrações testadas. Assim, sugere-se que a atividade ovicida em $F$. hepatica seja devido à presença desses compostos bioativos.

Palavras-chave: Eugenia uniflora L., Harpagophytum procumbens, Psidium guajava L., Stryphnodendron adstringens, atividade ovicida sobre Fasciola.

\section{INTRODUCTION}

Fasciolosis is a zoonosis caused by the liver fluke from Fasciola genus, thus generating substantial public health concern (MAS-COMA et al., 2014). Its main impact is on veterinary science, especially in sheep and cattle breeding, as it causes substantial economic losses due to condemnation of livers and animal carcasses in addition to reduced milk productivity, contamination of livers, weight 
loss and susceptibility to other diseases (SILVA et al., 2008).

OLIVEIRA \& RESENDE (2017), in their study on historical-geographical tracking, point to Fasciola hepatica are present throughout Brazil in the coming years, saw its versatility of infection, in the presence of its intermediate host throughout the national territory and especially due to the transport of animals between the Brazilian regions. Thus, it is essential to control fasciolosis to minimize the negative impacts on the economy.

The main form of control of $F$. hepatica infection is the use of anthelmintics. Benzimidazole are known to prevent the hatching of flukes and roudworm eggs (ALVAREZ et al., 2009), among them the halogenated triclabendazole derivative is the most efficient in controlling $F$. hepatica as it targets adults, larvae and eggs (BORAY et al., 1983; BEESLEY et al., 2017). However, this overreliance on triclabendazole has inevitably resulted in the emergence of triclabendazole-resistance in liver fluke populations (BEESLEY et al., 2017). Besides that, triclabendazole is no longer available in Brazil due to low demand and high cost.

There are other drugs available in Brazil to treat animals infected with $F$. hepatica and most of them have report of resistance (ALVES \& MARTINS, 2013). Thus, in addition to concerns about resistance, consumer demand for alternatives to synthetic products has spurred research on the use of medicinal plants in the worm control (TARIFA, 2001).

Another important matter is that secondary metabolites such as alkaloids, terpenes, tannins or flavonoids contained in crude plant extracts have been found related to parasiticidal activity (MERCADO et al., 2015). Hence, it is necessary to determine the chemical composition of the extracts because the validation of efficacy is an essential step for the correct use of products of plant origin as well as their active compounds (COSTA et al., 2002).
As environmental contamination by $F$. hepatica eggs is a major problem faced, more effective measures are needed to control this parasitosis. Thus, the aim of this study was to determine the phytochemical constituents of extracts of Eugenia uniflora L., Harpagophytum procumbens, Psidium guajava L. and Stryphnodendron adstringens and to evaluate the efficacy in ovicidal activity on Fasciola hepatica eggs.

\section{MATERIALS AND METHODS}

\section{Preparation of ethanol plant extracts}

The plant samples used were obtained from Pharmaceutical Production Laboratory of the Federal University of Espírito Santo. The plant collection was established by collecting native species from various locations in the states of Espírito Santo and São Paulo, Brazil. Exotic species that are not cultivated typically in Brazil were obtained from specialized suppliers (Table 1).

The plant materials were dried at $45{ }^{\circ} \mathrm{C}$ under forced air circulation (4-5 days) and were milled using knife mill ( $0.5 \mathrm{~mm}$ mesh size). The powdereddried materials were extracted by maceration in analytical grade alcohol at RT, by soaking $100 \mathrm{~g}$ gram powder in $1 \mathrm{~L}$ solvent. Each plant extract was prepared in triplicate. Solvent was filtered through Whatman cellulose filter paper and concentrated at $40{ }^{\circ} \mathrm{C}$ under reduced pressure (Laborota 4001, Heidolph). Aliquots of the extracts were partitioned between analytical grade ethyl acetate $(2 \times 400 \mathrm{~mL})$ and deionized water $(400 \mathrm{~mL})$ to remove lipophilic pigments. Finally, the aqueous layer of each triplicate was collected and lyophilized (L101, Liotop).

\section{Phytochemical analysis of plant extracts \\ Qualitative characterization of the} chemical composition of plant samples was performed according to WAGNER (1984) and MATOS (2009), with minor modifications. The search for alkaloids

Table 1 - Plant species selected for in vitro evaluation of anti-helminthic activity against $F$. hepatica eggs.

\begin{tabular}{|c|c|c|c|c|}
\hline Scientific name & Initials & Part & Collection & Code \\
\hline Eugenia uniflora & EUL & Leaves & VIES $^{\mathrm{a}}$ & VIES30550 \\
\hline Harpagophytum procumbens & HPR & Roots & Massaro $^{b}$ & 7890529283225 \\
\hline Psidium guajava & PGL & Leaves & VIES $^{\mathrm{a}}$ & VIES30552 \\
\hline Stryphnodendron adstringens & SAB & Barks & Massaro $^{\mathrm{b}}$ & 7898529281047 \\
\hline
\end{tabular}

${ }^{\mathrm{a}}$ Central Herbarium of the Federal University of Espírito Santo VIES, Jerônimo Monteiro-ES; ${ }^{\mathrm{b}}$ Comercial Massaro, Ribeirão Preto-SP. 
used the following reagents: Dragendorff (orange precipitate), Mayer (white precipitate), Bertrand (white precipitate), Bouchardat (brown precipitate), Sonnenschein (white precipitate), and Hager (yellow precipitate). For anthraquinones, the Bornträger reaction was used to observe the alkaline red color phase indicating positive reactions.

For cardiac glycosides, we used the Kedde reaction that reveals the presence of cardenolide rings as brown-reddish color solutions, in combination with a Legal reaction that gives a reddish color due to lactonic rings and the Keller-Kiliani reaction for free deoxy sugar analysis.

Coumarins were determined using the application of the extracts on paper filter, followed by addition of $10 \% \mathrm{KOH}$ and observation under UV light. The occurrence of flavonoids was determined as proposed based on the combination of the reactions of Shinoda, Pew, and Taubock using 3\% aluminum chloride under UV light (245 and $360 \mathrm{~nm}$ ).

The presence of phenolic compounds was tested by adding drops of $5 \% \mathrm{FeCl}_{3}$ in all sample extract solutions $(100 \mathrm{mg} / \mathrm{ml})$; the formation of a dark precipitate indicated positive reactions. To verify the presence of saponins in the extracts, aqueous solutions of the extracts were prepared, and foaming of the solutions was analyzed.

Tannins were screened by using solutions of $2 \%$ gelatin, $10 \%$ lead acetate and 3\% cupper acetate that produce characteristic precipitates. Terpenic compounds were determined using the Liebermann-Buchard reaction, with the formation of blue-greenish or pinkish rings in the interface layer indicating steroidal or triterpenic nuclei, respectively.

The assays were performed in triplicate. As a positive control for the phytochemical tests, we used extracts from plants that had been previously reported to possess these compounds.

\section{Evaluation of the ovicidal efficacy of plant extracts against $F$. hepatica eggs.}

For this experiment, $F$. hepatica eggs were collected from the gallbladder of cattle diagnosed with fasciolosis on post mortem examination. The eggs, along with the bile fluid, were stored in glass vials and transported to the parasitology lab at veterinary Hospital of the Federal University of Espírito Santo (Hospital Veterinário da Universidade Federal do Espírito Santo, HOVET-UFES).

To evaluate the ovicidal activities, the nine crude extracts of plants were dissolved in $0.1 \%, 0.25 \%$ and $0.5 \%$ deionized water. 100 eggs were collected and transferred to $50-\mathrm{mL}$ Falcon ${ }^{\circledR}$ tubes, and $3 \mathrm{~mL}$ of the plant extracts were added in each tube. The assays were performed in triplicate. The positive and negative controls consisted of albendazole at $0.5 \%$ and tap water (FAIRWEATHER et al., 2012), respectively.

Falcon $^{\circledR}$ tubes were wrapped in aluminum foil to prevent light exposure and were placed in a biochemical oxygen demand (BOD) chamber for 14 days at $25^{\circ} \mathrm{C}$. The samples were then exposed to $100 \mathrm{~W}$ incandescent light bulbs for 3 hours (FAIRWEATHER et al., 2012). Egg counts were performed once every hour during the 3-hour light exposure using a stereoscopic microscope at $2 \mathrm{x}$ magnification. At the end of the hatching analysis, the eggs were pipetted and deposited onto slides with water and covered with a coverslip for morphological analysis. Egg size, external wall integrity, miracidium formation and operculum opening were evaluated using light microscopy (Binocular Microscope Novel BM1000 LED) with the 40x and 100x objective lenses.

The efficacy, expressed as a percentage, was estimated for each extract using the following formula:

$$
\text { Efficacy }(\%)=\frac{\text { mean negative control }- \text { mean of extracts treatment }}{\text { mean negative control }} \times 100
$$

Extracts with a statistically significant difference between treatment and control groups with efficacy $\geq 90 \%$ were considered effective (WOOD et al., 1995). Analysis of variance at $p<0.05$ was performed, and means were compared using the Tukey's test at $\mathrm{p}<0.05$, using Assistat ${ }^{\circledR}$ online.

\section{RESULTS AND DISCUSSION}

The results of the phytochemical analysis of the extracts of four plants used in this study are summarized in table 2. Extract analysis of E. uniflora leaves (EUL) revealed the presence of phenolic compounds, tannins and terpenoids. Literature data suggested the presence of these and other metabolites of the genus Eugenia; FIUZA et al. (2008) observed the presence of tannins, steroids, triterpenes, heterosides, anthraquinones, saponins, flavonoids, sesquiterpenes, and phenolic compounds. The phytochemical analysis of $H$. procumbens root (HPR) extract revealed the presence of phenolic compounds and terpenoids. The literature suggested that $H$. procumbens roots are composed mainly by iridoids, main active compound of which is harpagoside, constituting $0.5 \%$ to $1.5 \%$ of the herbal drug (ROSA, 2007).

In our study, the analysis of $P$. guajava L. leaves (PGL) revealed the presence of phenolic compounds, including flavonoids and tannins, terpenoids. WANG et al. (2014) showed that $P$. 
Table 2 - Phytochemical analysis of the plant species selected for in vitro evaluation of anti-helminthic activity against $F$. hepatica eggs

\begin{tabular}{|c|c|c|}
\hline Metabolite & Test performed & Results \\
\hline Alkaloids & Dragendorff, Mayer, Bertrand, Bouchardat, Sonnenschein, Hager & None \\
\hline Anthraquinones & Bornträger & None \\
\hline Cardiac glycosides & Kedde, Legal, Pesez, Keller-killiani & None \\
\hline Coumarins & $\mathrm{KOH} 10 \%$ & None \\
\hline Flavonoids & $\mathrm{AlCl}_{3}$, Pacheco, Shinoda, Pew; Taubouk & None \\
\hline Phenolics & $\mathrm{FeCl}_{3}$ & EUL, HPR, PGL, SAB \\
\hline Saponins & Stable foam formation & None \\
\hline Tannins & Gelatin $2 \%, \mathrm{~Pb}(\mathrm{AcO})_{2}, \mathrm{FeCl}_{3} 1 \%, \mathrm{Cu}(\mathrm{AcO})_{2}$ & $\mathrm{EUL}^{1}, \mathrm{PGL}^{1}, \mathrm{SAB}^{2}$ \\
\hline Terpenoids & Liebermann-Buchard & EUL, HPR, PGL, SAB \\
\hline
\end{tabular}

EUL: E. uniflora leaves; HPR: H. procumbens roots; PGL: P. guajava L. leaves; SAB: S. adstringens bark; ${ }^{1}$ Hydrolysable Tannins, ${ }^{2}$ Condensed Tannins.

guajava L. leaves are composed of large amounts of phenolic compounds, including gallic acid, catechin, epicatechin, rutin, quercetin and monoheteroside derivatives, an essential oil composed of sesquiterpenes $(54.9 \%)$ and low molecular weight volatile compounds, mainly hexanal aldehydes (65.9\%). MARTINS et al. (1995) reported the presence of tannins in $P$. guajava L. that potentially prevent the penetration of tissues and mucous membranes by harmful agents that are responsible for the plant's anti-diarrheal properties.

Phytochemical analysis of $S$. adstringens bark (SAB) revealed the presence of phenolic compounds, flavonoids and tannins in the bark extracts and terpenoids in the leaf extracts. High molecular weight proanthocyanidins and other condensed tannins (flavan-3-ols, prodelphinidins and prorobinetinidins) were identified in $S$. adstringens (MELLO et al., 1996a, 1996b, 1999). MACEDO et al. (2008) showed that $S$. adstringens leaves can be used as a source of phenolic compounds, mainly flavonoids and tannins. In leaves, these compounds deter herbivores and other pathogenic actors. $S$. adstringens is rich in tannins and other chemical classes, including flavonoids, terpenes, stilbenes, steroids and protease inhibitors (such as trypsin) that may be responsible for its anti-inflammatory activity and supposed antimicrobial activity (VASCONCELOS et al., 2004).

In the in vitro test to determine the efficacy of extracts on $F$. hepatica eggs, all plant extracts tested at concentrations of $0.1 \%, 0.25 \%$ and $0.5 \%$ had activities that were significantly different from the negative (water) and positive (albendazole) controls; all extracts inhibited larval development or egg hatching (Table 3). According to POWERS et al. (1982), extracts with efficacies greater than or equal to $90 \%$ were highly effective and those with efficacies between $80 \%$ and $90 \%$ were moderately effective. However, WOOD et al. (1995) declared that efficacy of a product for nematodes, trematodes and cestodes, should be expressed for each genus/species (larvae/adults) as follows: highly effective (over 98\%), effective $(90 \%-98 \%)$, moderately effective $(80 \%-89 \%)$ or insufficiently active (less than $80 \%$ ).

In our study, the extracts of EUL $0.10 \%$, HPR $0.25 \%$, PGL and SAB at concentrations of $0.10 \%, 0.25 \%$ and $0.50 \%$ showed high efficacy. The $0.50 \%$ HPR extract was effective, while at the $0.25 \%$ concentration, it was moderately effective. For the extracts of EUL, HPR, PGL and SAB, there were no significant differences between the three tested concentrations, and the activities of these extracts were only significantly different from the negative control, showing that they were effective in preventing the hatching of $F$. hepatica miracidia.

In microscopic analysis of eggs, tap water did not prevent the hatching of miracidia from $F$. hepatica eggs, allowing the operculum to remain open. By contrast, albendazole, used as a positive control, prevented egg hatching, resulting in non-viable eggs, with no miracidium formation in their interior. The surface was not changed in any of the experimental conditions. The bark of $S$. adstringens allowed formation of miracidium; however, they did not hatch. In the literature we found no reports of the efficacy of these plant extracts on $F$. hepatica (Figure 1). MERCADO et al. (2015) reported that secondary metabolites such as alkaloids, terpenes, tannins and flavonoids in crude 
Table 3 - Quantitative evaluation of hatchability and efficacy on Fasciola hepatica eggs after incubation with plant extracts within 3 hours of experiment.

\begin{tabular}{|c|c|c|c|c|c|c|}
\hline \multirow[t]{2}{*}{ Treatment } & \multirow[t]{2}{*}{ Concentration } & \multicolumn{3}{|c|}{ 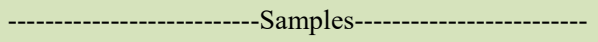 } & \multirow[t]{2}{*}{ Mean } & \multirow[t]{2}{*}{ Efficacy $(\%)$} \\
\hline & & S01 & S02 & S03 & & \\
\hline EUL & $0.10 \%$ & 0 & 0 & 0 & 0 & 100 \\
\hline HPR & $0.10 \%$ & 10 & 12 & 18 & 13,33 & 88.20 \\
\hline HPR & $0.25 \%$ & 0 & 0 & 0 & 0 & 100 \\
\hline HPR & $0.50 \%$ & 2 & 22 & 0 & 8 & 92.92 \\
\hline PGL & $0.10 \%$ & 1 & 0 & 1 & 0.66 & 99.41 \\
\hline PGL & $0.25 \%$ & 0 & 0 & 0 & 0 & 100 \\
\hline PGL & $0.50 \%$ & 0 & 0 & 0 & 0 & 100 \\
\hline SAB & $0.10 \%$ & 0 & 0 & 0 & 0 & 100 \\
\hline SAB & $0.25 \%$ & 0 & 0 & 0 & 0 & 100 \\
\hline SAB & $0.50 \%$ & 0 & 0 & 0 & 0 & 100 \\
\hline Albendazole & $0.50 \%$ & 0 & 0 & 0 & 0 & 100 \\
\hline \multicolumn{2}{|c|}{--------------------Tap water------------------- } & 116 & 102 & 121 & 113 & 0 \\
\hline
\end{tabular}

*EUL: E. uniflora leaves; HPR: H. procumbens roots; PGL: P. guajava L. leaves; SAB: S. adstringens barks.

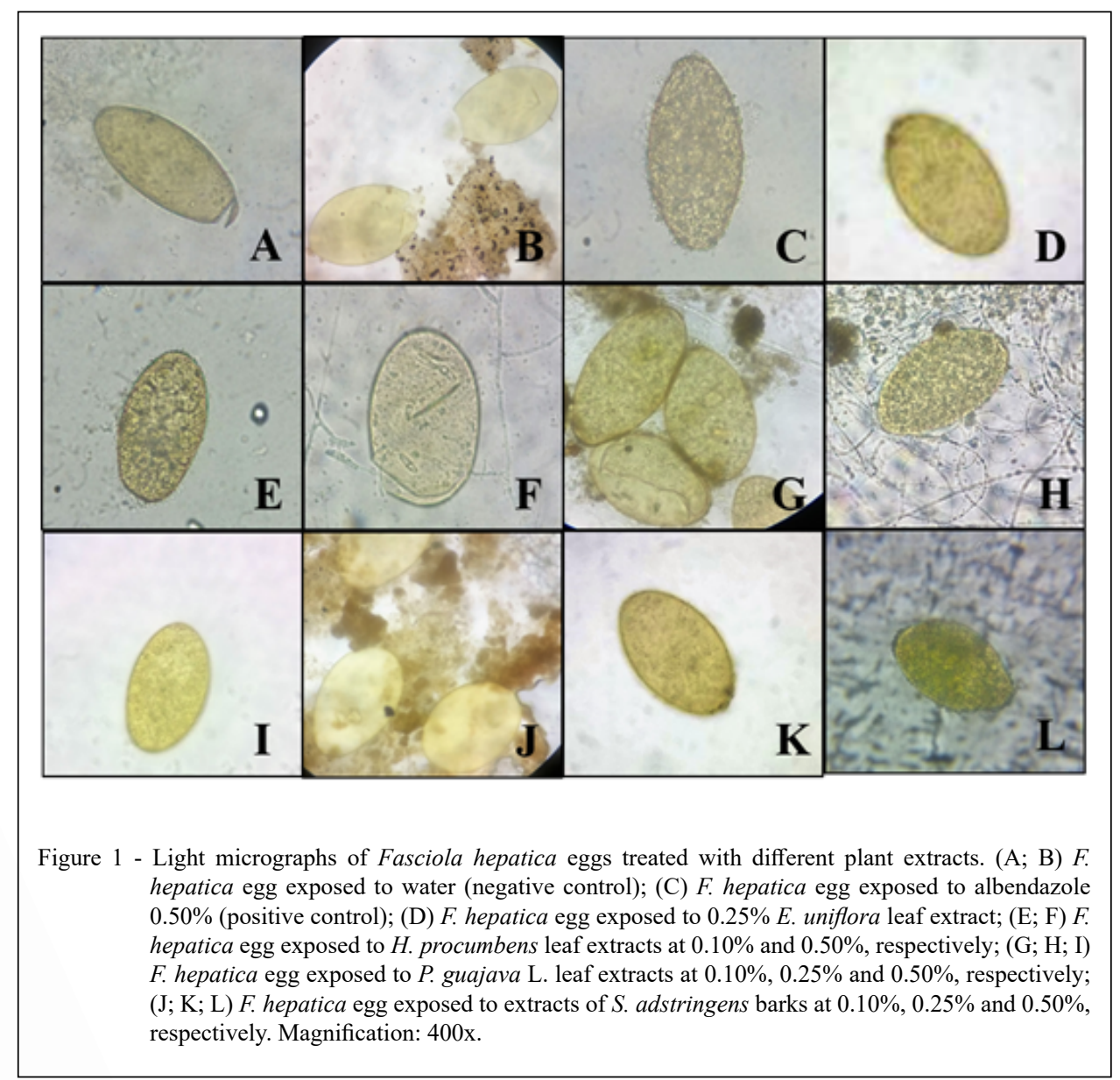

Ciência Rural, v.50, n.5, 2020. 
plant extracts have anti-parasitic activity. Nevertheless, because these are not the only compounds produced by plants, the effects of other bioactive compounds cannot be ruled out. Therefore, determination of the chemical composition of extracts that exhibit antihelminthic activity is necessary.

In this study, all extracts were positive for tannins, suggesting that these compounds might be responsible for the biological activity that prevented miracidium hatching. It is also believed that the extracts that precluded miracidium hatching could have also altered morphology. A mechanism of tannin inhibition of miracidium hatching is binding of these compounds with proteins and other macromolecules. Given that tannins have astringent characteristics, they also display toxic properties. Another mechanism of tannin toxicity is binding with heavy metals. Biological systems, including microorganisms, require heavy metals as enzyme cofactors. For example, mice given phenolic-rich liquid as their fluid source showed decreased iron absorption (SCALBERT, 1991).

\section{CONCLUSION}

The tests performed with $F$. hepatica eggs revealed that Eugenia uniflora, Harpagohytum procumbens, Psidium guajava L. and Stryphnodendron adstringens exhibited high efficacy in the control of egg hatching, at the doses used. These extracts precluded miracidium hatching, and in some cases, precluded miracidium formation inside the egg. Phytochemical analysis revealed the presence of phenolic compounds, tannins and terpenoids in the extracts, with phenolic compounds and terpenoids being the predominant compounds in all plant extracts tested. The results suggested that these compounds could be responsible for the biological activity that prevented miracidium hatching.

\section{ACKNOWLEDGEMENTS}

This study was financed by the Fundação de Amparo à Pesquisa e Inovação do Espírito Santo (FAPES) and was financed in part by the Coordenação de Aperfeiçoamento de Pessoal de Nível Superior (CAPES), Brasil - Finance code 001.

\section{BIOETHICS AND BIOSSECURITY COMMITTEE APPROVAL}

This study was approved by the Animal Use Ethics Committee of the Federal University of Espírito Santo under number 6102/2015.

\section{DECLARATION OF CONFLICT OF INTERESTS}

The authors declare no conflict of interest. The founding sponsors had no role in the design of the study; in the collection, analyses, or interpretation of data; in the writing of the manuscript, and in the decision to publish the results.

\section{AUTHORS' CONTRIBUTIONS}

LTC, RAG and WDR performed data curation, formal analysis, developed the methodology and wrote the original draft. ABA performed writing, review and editing. IVFM and JAS performed the conceptualization, funding acquisition, project administration and supervision. All authors critically revised the manuscript and approved of the final version.

\section{REFERENCES}

ALVAREZ, L. et al. Comparative assessment of albendazole and triclabendazole ovicidal activity on Fasciola hepatica eggs. Veterinary Parasitology, v.164, n.2, p.211-216, 2009. Available from: <http:/www.sciencedirect.com/science/article/ pii/S0304401709003069>. Accessed: Mar. 17, 2019. doi: 10.1016/j.vetpar.2009.05.014.

ALVES, D. P.; MARTINS, I. V. F. Updates on parasite control of fascioliasis in cattle. Enciclopédia Biosfera, v.9, n.16, p.323-351, 2013. Available from: <http://www.conhecer.org.br/enciclop/2013a/ agrarias/atualizacao.pdf>. Accessed: Dec. 07, 2019.

BEESLEY, N. J. et al. Fasciola and fasciolosis in ruminants in Europe: Identifying research needs. Transboundary and Emerging Diseases, v.65, n.S1, p.199-216, 2018. Available from: $<$ https://onlinelibrary.wiley.com/doi/full/10.1111/tbed.12682>. Accessed: Dec. 07, 2019. doi: 10.1111/tbed.12682.

BORAY, J. C. et al. Treatment of immature and mature Fasciola hepatica infections in sheep with triclabendazole. Veterinary Record, v.113, n.14, p.315-317, Out. 1983. Available from: $<$ http://veterinaryrecord.bmj.com/content/113/14/315.abstract $>$. Accessed: Feb. 25, 2019. doi: 10.1136/vr.113.14.315.

COSTA, C. T. C. et al. Ovicidal effect of Mangifera indica 1 . seeds extracts on Haemonchus contortus. Revista Brasileira de Parasitologia Veterinaria, v.11, n.2, p.57-60, 2002. Available from: $<$ http://www. ufrrj.br/rbpv/1122002/c11257_60.pdf>. Accessed: Dec. 07, 2019.

FAIRWEATHER, I. et al. Development of an egg hatch assay for the diagnosis of triclabendazole resistance in Fasciola hepatica: Proof of concept. Veterinary Parasitology, v.183, n.3, p.249-259, 2012. Available from: <https://www.sciencedirect.com/science/ article/pii/0304401795008062?via\%3Dihub>. Accessed: Mar. 01, 2019. doi: 10.1016/0304-4017(95)00806-2.

FIUZA, T. S. et al. Pharmacognostic characterization of the leaves of Eugenia uniflora L. (Myrtaceae) . Revista Eletrônica de Farmácia, v.5, n.2, p.1-11, 2008. Available from: $<$ https://revistas. ufg.br/REF/article/view/5148>. Accessed: Mar. 17, 2019. doi: $10.5216 /$ ref.v5i2.5148.

MACEDO, F. M. et al. Triagem fitoquímica do barbatimão [Stryphnodendron adstringens (Mart) Coville. Revista Brasileira de Biociências, v.5, n.s2, p.1166-1168, 2008. Available 
from: <http://www.ufrgs.br/seerbio/ojs/index.php/rbb/article/ view/1026/765>. Accessed: Mar. 13, 2019.

MARTINS, E, R.; et al. Plantas Medicinais. Viçosa: Imprensa Universitária, 1995. 220p.

MAS-COMA, S. et al. Chapter Two - Neurological and Ocular Fascioliasis in Humans. Advances in Parasitology, v.84, p. 27-149, 2014. Available from: <https://www.sciencedirect.com/science/ article/pii/B9780128000991000028?via\%3Dihub>. Accessed: Feb. 24, 2019. doi: 10.1016/B978-0-12-800099-1.00002-8.

MATOS, F. J. A. Introdução a fitoquímica experimental. Fortaleza: Edições UFC, 2009. 141p.

MELLO, J. C. P. et al. A dimeric proanthocyanidin from Stryphnodendron adstringens. Phytochemistry, v.51, n.8, p.1105-1107, 1999. Available from: <http://www.sciencedirect. com/science/article/pii/S0031942298007158>. Accessed: Mar. 16, 2019. doi: 10.1016/S0031-9422(98)00715-8.

MELLO, J. C. P. et al. A. Flavan-3-ols and prodelphinidins from Stryphnodendron adstringens. Phytochemistry, v.41, n.3, p.807813, Fev. 1996a. Available from: <https://www.sciencedirect.com science/article/abs/pii/0031942295006869>. Accessed; Mar. 16, 2019. doi: 10.1016/0031-9422(95)00686-9.

MELLO, J. C. P. et al. Prorobinetinidins from Stryphnodendron adstringens. Phytochemistry, 1996b, v.42, n.3, p.857-862, Jun. 1996b. Available from: <https://www.sciencedirect.com/science/ article/abs/pii/0031942295009531>. Accessed: Feb. 24, 2019. doi: 10.1016/0031-9422(95)00953-1.

MERCADO, J. M. A. et al. In vitro antihelmintic effect of fifteen tropical plant extracts on excysted flukes of Fasciola hepatica. BMC Veterinary Research, v.11, p.e45, 2015. Available from: <https:// bmcvetres.biomedcentral.com/articles/10.1186/s12917-015-0362-4>. Accessed: Mar. 14, 2019. doi: 10.1186/s12917-015-0362-4.

OLIVEIRA, D. M.; RESENDE, P. O. Fasciola hepatica: ecology and historical-geographical trajectory in Brazil. Estação Científica, v.7, n.2, p.09-19, 2017. Available from: <https://periodicos.unifap. br/index.php/estacao/article/viewFile/3051/darlanv7n2.pdf >. Accessed: Dec. 07, 2019. doi: 10.18468/estcien.2017v7n2.p09-19.

POWERS, K. G. et al. World Association for the Advancement of Veterinary Parasitology (W.A.A.V.P) guidelines for evaluating the efficacy of anthelmintics in ruminants (bovine and ovine).
Veterinary Parasitology, v.10, n.4, p.265-284, Jul. 1982. Available from: <https://www.sciencedirect.com/science/article/ pii/0304401782900784?via\%3Dihub>. Accessed: Mar. 13, 2019. doi: 10.1016/0304-4017(82)90078-4.

ROSA, C. R.; MACHADO, C. A. Herbal medications for the treatment of rheumatics disease: a review. Revista Brasileira de Farmácia, v.88, n.1, p.26-32, 2007. Available from: $<$ http://www.rbfarma.org.br/files/PAG26a32_PLANTAS.pdf>. Accessed: Mar. 14, 2019.

SCALBERT, A. Antimicrobial properties of tannins. Phytochemistry, v.30, n.12, p.3875-3883, 1991. Available from: <https://www.sciencedirect.com/science/article/abs/ pii/003194229183426L >. Accessed: Feb. 24, 2019. doi: 10.1016/0031-9422(91)83426-L.

SILVA, E. R. V. et al. Fasciolose hepática. Revista Científica Eletrônica de Medicina Veterinária, v.06, n.11, p.1-7. 2008. Available from: $<$ http://www.faef.revista.inf.br/imagens arquivos/ arquivos_destaque/bZFsg7XYKOHoLIt_2013-6-13-16-23-55. pdf>. Accessed: Dec. 07, 2019.

VASCONCELOS, M. C. et al. Evaluation of biological activities of the seeds of Stryphnodendron obovatum Benth. (Leguminosae). Revista Brasileira Farmacognosia, v.14, n.2, p.121-127, 2004. Available from: $<$ http://www.scielo.br/scielo.php?script $=$ sci abstract\&pid $=$ S0102-695X2004000200005\&lng $=$ en \&nrm $=\bar{i}$ so\&tlng=pt $>$. Accessed: Mar. 23, 2019. doi: 10.1590/S0102$695 \times 2004000200005$.

WAGNER, H. et al. Plant drug analysis: a thin layer chromatography atlas. Berlin: Springer Verlag, 1984.

WANG, F. et al. Chemical Components and Bioactivities of Psidium guajava. International Journal of Food Nutrition and Safety, v.5, n.2, p.98-114, 2014. Available from: <http:// modernscientificpress.com/Journals/ViewArticle.aspx?6 ZIT7 oAL6Lqarm6Ljqm1 AAxP30a97ugrPxLcENGR3R// uHsKHg1MC9pBPxmjKUtY>. Accessed: Feb. 10, 2019.

WOOD, I. B. et al. World Association for the Advancement of Veterinary Parasitology (W.A.A.V.P.) second edition of guidelines for evaluating the efficacy of anthelmintics in ruminants (bovine, ovine, caprine). Veterinary Parasitology, v.58, n.3, p.181-213, Jun. 1995. Available from: <https://www.sciencedirect.com/ science/article/pii/0304401795008062?via\%3Dihub>. Accessed: Feb. 14, 2019. doi: 10.1016/0304-4017(95)00806-2. 